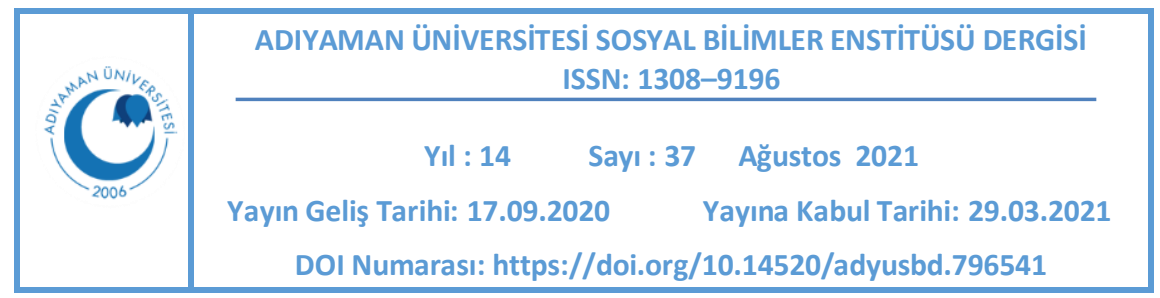

\title{
YAZINSALDAN GÖRSEL SOMUTLAŞTIRMAYA ÜTOPYALARDA MEKAN KURGUSU
}

\section{Veda Seven BIÇEN*}

\begin{abstract}
$\ddot{O z}$
Bilinçli bir varlık olan insan nesiller boyu dönemlerini şekillendiren fikirler üretmişlerdir. Birlikte yaşamın getirdiği sorunlarla mücadele etme çabaları, toplumları ideal düzen arayışına itmiştir. Ortaya çıkan fikirler edebiyatta yazınsal olarak gelişmiştir. Dönemlerinin eleştirisi niteliğinde olan ve çözüm önerisi sunmaya çalışan ütopyalar, 19.yy'da endüstri devriminin yarattığı kaosa karşılık mimarlıkta yansımalarını bulmuştur. ilk olarak mimari ürünlerle somutlaştırılmaya çalışılan ütopyalar, 20.yy'da sinema sanatının çıkışıla beraber sistematik olarak görselleştirilmeye başlanmıştır. Döneminin sorunlarını çözebilme kaygısı olan, geleceğin formlarını ve/veya fonksiyonlarının değişimini bilimsel/teknolojik gelişmelerle tasarlayabilme mimarlık ütopyalarını oluştururken, sinemada bu ütopyalar, distopyalar olarak bilim kurgu filmleriyle nesnelleşmiştir. Ütopik mekân kurgusunu yansıttığı düşünülen örnek filmler seçilmiş ve çıkarımlar yapılmıştır.
\end{abstract}

Anahtar Kelimeler: Ütopya, Distopya, Mimarlık Ütopyaları, Sinemada Mekân Kullanımı, Bilim Kurgu Sineması.

Dr. Arş. Gör., Bitlis Eren Üniversitesi Mühendislik Mimarlık Fakültesi Mimarlık Bölümü, vsbicen@gmail.com 


\title{
FROM LITERARY TO VISUAL REIFICATION SPACE SETUP IN UTOPIAS
}

\begin{abstract}
Human beings, a conscious being, have produced ideas that have shaped their periods for generations. Efforts to tackle the problems of living together have pushed societies to seek an ideal order. The emerging ideas developed literarily in literature. Utopias, which are criticism of their periods and try to offer a solution proposal, found their reflections in architecture in response to the chaos created by the industrial revolution in the 19th century. Utopias, which were first tried to be embodied with architectural products, started to be systematically visualized with the advent of cinema art in the 20th century. While solving the problems of the era and designing the change of the forms and/or functions of the future, which are concerned about their solutions, with scientific/technological developments, utopias are formed by science fiction films as dystopias. Some sample films thought to reflect the utopian space setup were selected and inferences were made.
\end{abstract}

Keywords: Utopia, Dystopia, Utopias in Architecture, Space Use in Cinema, Science Fiction Cinema.

\section{GiRiş}

Bilinçli bir varlık olan insan nesiller boyu dönemlerini şekillendiren fikirler üretmişlerdir. Geleceğini, tecrübe ve öngörüleriyle şekillendiren insanların, epik anlatımlar içeren bu fikirlerdeki temel gayesi ideal bir düzende verimli bir yaşam tarzını sürdürebilmek olmuştur. Birlikte yaşamın getirdiği kaçınıımaz sorunlarla mücadele etme çabaları, bireyleri/toplumları ideal düzen arayışına itmiştir. Burada ideal düzen ile kastedilen fiziksel, sosyal, siyasal, kültürel ve ekonomik açıdan dengeli, sürekli ve uyumlu bir yaşam tarzıdır. Bu eğilim çerçevesinde ideal düzen fikri, bulunulan dönemin koşullarını eleştirirken veya şekillendirirken, geleceğin olasılıklarına dair varsayımları da beraberinde getirmiştir. Sürekli aranılan ideal düzen fikrinin açmazı, pratikte karşılı̆ııı tam olarak bulamamasıdır. 
Bu nedenle arayış, fikirsel anlamda bir arzu olarak kalmakta, eleştiri ve önerilerle dönemin sorunlarına göre gelişmeye devam etmektedir. İdeal yeri/toplumu/sistemi yaratma gayesinde olan ütopyalar gelenekselleşmeye başladığı 16.yy'dan bu yana fikirsel olarak edebiyat, mimarlık ve sinemada bir arzu ve/veya temsil olarak yer etmiştir. Bir arzu olarak kalan ideal düzen fikri ilk olarak tepkileri azaltmak, sonrasında coğrafi keşiflerin verdiği heyecanla, farklı yerlerin var olma olasılığını kullanmak adına edebiyatta kurgulanırken, olmayan bir yerde betimlenmiştir. Olmayan yer "ütopya” kavramı ile 16.yy'da literatüre girmiştir.

Edebiyatta kullanılmaya başlanan ütopyalar, diğer bir deyişle olmayan yerdeki ideal düzen fikri, üretim ve tüketim dengesini değiştiren Endüstri Devriminin, toplumlara verdiği zararlar sonrasında yoğun olarak kullanılmaya başlanmıştır. Bu dönemde sınıf farklılıklarının derinleşmesi ve bunların yaratmış olduğu kaos ortamı; sosyal ütopyacılar, kent tasarımcıları ve mimarlar tarafından analiz edilip, eleştirilerek, somut çözümler sunulmaya çalışılmıştır. Kent ve kent modüllerinin tasarımları ile ütopya kurguları somutlaştırılmaya doğru evrilmiştir. Bu dönemle başlayan ve sonrasında karşılaşılan sorunlarla şekillenen tasarımlar eskiz çalışmaları veya münferit inşalar olarak kalmıştır. Üretim şekillerinin, enerji kaynaklarının, çevresel dengenin ve otorite güçlerinin, devamlı değiştiği ve değiştirdiği dinamikler göz önüne alındığında, 20.yy ve sonrasında ütopik fikirlerin, mimari akımlar ve oluşumlar içerisinde yer ettiği görülmektedir. Barınma gereksinimi ile temellenen mimarlık; toplumların kültürleri, inançları, sosyal ve ekonomik şartları, savaşları, enerji kaynaklarının kullanımı, üretim/tüketim biçimleri ve coğrafyaları ile değişim göstermektedir. Sürekli değişen ve gelişen mimarlık yaklaşımları, ütopik fikirlerin etkisiyle ideal düzeni, ideal mekânda yaratma sürecini, geleceğin varyasyonları ile şekillendirerek farklı oluşum ve fikirleri de temsil etmeye başlamıştır. Temsil yoluyla öne sürülen anlatımların geleceğe dair bir bilinç yaratabilmesi, yeni fikirler ve oluşumların 
yaygınlaştırılması için toplumlara benimsetilmesi gerekmektedir. Bu nedenle çalışmada ütopik mekân kurgusu incelenirken, toplumların farklı coğrafyalarda ve kültürlerde kullandıkları en yaygın ve etkin, iletişim ve algı yönlendirme aracı olma özelliği taşıyan sinema sanatı irdelenmiştir. Ortak paydası insan ve mekân olan sinema-mimarlık arasındaki ilişki; sembolik olma, algı yaratma, bellek olma gibi özellikler ile tasarımda benzer üretim tekniklerini kullanma ve mekân oluşturma gerekliliği çerçevesinde sürekli gelişmiştir (Akyıldız, 2012; Düştegör, 2011; Bozdoğan, 2008; Akkuş, 2008; Ergin, 2007, Gülüş, 2006). Ayrıca filmler kadar açık ve/veya kapalı sinemalarda bulundukları zaman kesitinde kentin farklı sosyo-ekonomik gruplarına sosyalleşme imkanı vermesi bakımdan önemli bir yere sahip olmuştur. Bu açıdan kentin sakinlerini bir araya getiren bir unsur olarak, sosyal ve kültürel yapısına etki ederek değerlendirmede bir ölçüt olarak alınmaktadır (Şahin ve ark. 2019).

Benzer akımlardan ve dinamiklerden beslenen, sinema ve mimarlık, eleştirel yaklaşımla; çözüm önerileri veya gelecek öngörülerini sunarken, geniş çapta kitleleri etkileme ve yönlendirme birbirinden faydalanabilmektedir. Sinemada gelecek varsayımları ve dönemin dinamikleri, bilimsel ve teknolojik gelişmelerin ışığında mimari ürünlerden yoğun olarak faydalandığı bilimkurgu türü filmlerde ortaya çıkmaktadır. Bu nedenle çalışmada ütopya kavramının mekân yaratma süreci edebiyat, mimarlık ve sinemanın ortak paydası olarak kabul edilmiş, bu açıdan değerlendirilmeye çalışılmıştır.

Ütopyaların işlendiği edebi eserlerde mimarlık araç olarak kullanılmıştır. Ancak mimarlık ve sinema etkileşimi daha doğrudan olmuştur. Sinema sanatı başlangıcından itibaren birçok sanat dallarıyla etkileşim içinde olmuştur. Görsel bir sanat oluşu mimarlık ile ilişkisini geliştirmiştir.

Mimarlık ve sinema arasındaki ilişki; hem mekân üzerinden kurulan etkileşim (Kaçmaz, 2001; Gülüş, 2006; İnce, 2007; Ergin, 2007; Sayar Güntan, 2007; Tüzün, 
2008; Sarı, 2010; Tunçok, 2010; Allmer, 2010), hem üretim teknikleri arasındaki ortak noktalar (Doğay Örs, 2001; Aydın, 2004; Bozdoğan, 2008; Alvarado, 2008; Ertem, 2010), hem de kentsel mekânın ile olan ilişki (Özakın, 2001; Akkuş, 2008; Öztürk, 2008; Ülker, 2011; Konca, 2011; Kayaarası, 2011; Düştegör, 2011) üzerinden şekillendiği görülmektedir. Süreç içerisinde ortak noktası mekân ve insan olan sinema mimarlık arasındaki ilişki güçlenerek devam etmiştir. Gerek mimarlığın sinemayı kullanımı, gerek sinemanın mimarlığı kullanımı her iki sanat dalına katkı sağlamıştır. Sinema ve mimarlık arasında farklı etkileşim şekilleri vardır. Mekân tasarımlarını, bilimsel ve teknolojik gelişmelerden faydalanarak kurgulamak, geleceğin mimarisini şekillendirmede farklı perspektifler oluşturmak, mimarlık ütopyalarını oluşturmaktadır. Bu ütopyalar; bilimkurgu filmlerindeki mekânların, üçboyutlu deneyimlenmesinde nesnelleşmektedir. Bu nedenle çalışma bilimkurgu türündeki ilk başyapıt olarak kabul edilen Metropolis filmi ve farklı dönemlerdeki yazınsal edebiyatta yer alıp, görsel somutlaştırma ile beyazperdeye taşınan filmlerin, mekân kurguları incelenerek, çıkarım yapılmaya çalışılmıştır.

\section{2. ÜTOPYA KAVRAMI VE YAZINSAL GELIŞiMi}

İdeal düzen kurgusunda, iyi/olmayan yerde tasvir edilen, ideal toplum ve yönetim sistemine dair anlatımların kökenleri; Mahabrata'daki Krita Yuga'ya, Eski Ahit’teki Aden'e, Homeros'un Odysseia'sına, Kuran'daki cennet tasvirlerine, Platon'un Devlet'ine, Farabi'nin El-Medinetü'l Fazılası'na kadar uzansa da kavram olarak ortaya çıkışı ve bir gelenek haline gelişi, Thomas More ile başlamıştır (Omay, 2009). Ütopya kavramı ilk olarak Sir Thomas More tarafından 1516 yılında "Utopia" adlı eseriyle ortaya atılmıştır (Omay, 2009). More, Yunanca "ou” yok ve "eu" iyi kelimelerinin ortak sesi " $u$ " ile yer anlamına gelen "topos" $u$ birleştirerek "var olmayan iyi yer" anlamında kullanmıştır (Canbaz Yumuşak, 2012). Coğrafi keşiflerin, yeni ve farklı yerleri sunması ile ideal düzeni oluşturma eğilimi önem 
kazanmış ve kavram gelenek haline gelmeye başlamıştır. Ütopyalar dönemlerin yaşama ve düşünme biçimi olarak gelişirken; hem ait olduğu düzene karşı çıkma/eleştirme hem de benzer ancak ideal yaşamı kurgulama eğilimi göstermişlerdir (Alver, 2009). Ortaya çıktığı ve gelenekleşmeye başladığı dönem olan 16. ve 17.yy'da Thomas More, Tomasso Campenella, Francis Bacon ve François Rabelias gibi yazarlar, verdikleri eserlerle ütopyaların gelişiminde ön plana çıkmaktadırlar. Thomas More, Ütopya'sında, dönemin İngiltere'sindeki monarşi sistemini eleştirerek, sosyalist sisteme yakın bir toplum teorisini anlatmıştır (Yücedağ, 2011). Tomasso Campenella ise İtalya'nın kaos ortamına karşı geliştirdiği totaliter devleti, Güneş Ülkesi'nde tasvir etmiştir (Dürüşken, 2012). Francis Bacon, Yeni Atlantis eserinde, bilimsel ve teknolojik gelişmenin vurgusunu yapmış ve "ideali" doğayı, insanlığın hizmetinde kullanmak olarak tanımlamıştır (Başaran, 2007). Dönemin baskıcı ve toplumsal ütopya tasvirlerinde; "ada" kurgusu ile sınırlandırılmış, coğrafik alanlardaki kentler, monoton ve lineer yapılarıyla yer almıştır.

18. ve 19.yy'da ise bilimsel ve teknolojik buluşlar, ütopyalara yön vermiştir. Bu dönemde buharlı makinelerin icadıyla başlayan Endüstri Devrimi, sınıf farklılıklarını derinleştirmiş, 19.yy'da protestolara neden olmuştur (Bayartan, 2009). Oluşan toplumsal sorunları çözmek, yaşam koşullarını iyileştirmek için ütopyacılar çeşitli öneriler geliştirmişlerdir. Bu dönemde, Charles Fourier, Etienne Cabet ve Robert Owen gibi isimler ön plana çıkmıştır (Engels, 2008). Dönemin girişimcileri, kurumların işleyişi ve yaşam alanlarının inşasında ütopyalardan yararlanmışlardır (Alver, 2009). Ütopyaların, mekân önerisi olma özelliği, kamusal ve özel alanların oluşumunda, kent planlamalarını etkilemiştir. İdeal yeri yaratma çabasıyla ortaya konan örneklere bir sonraki bölümde yer verilmiştir.

20.yy ve sonrasında, dünya ölçeğinde gelişen, farklı siyasi ve ekonomik sistemlerin uygulamaları (sosyalizm, kapitalizm, nasyonal sosyalizm), nükleer 
savaş gerilimleri, teknolojik gelişmelerin yarattığı soğuk savaş düzeni, ekolojik dengenin bozulmaya başlaması, etnik ve sınıfsal farklılıkların yarattığı sorunlar, ütopyaların sunduğu, çözümleyici gelecek önerilerinin yerine karşı ütopyaları/ distopyaları (karamsar kurguları) ön plana çıkartmıştır. Köken olarak distopya terimi John Stuart Mill tarafından 1868 yılında ortaya atılmıştır ve hayal edilebilecek "en kötü" yeri, yönetimi ve koasu tanımlamak için kullanılmıştır (Başaran, 2007). Kavram 20.yy'da sıkça işlenmeye başlanmıştır. Ütopyaların iyimser ve toplumsal yapısının yerine, toplumsal uyum adına yaratılan baskıcl, tek tipçi ve kapalı düzenin, yaratacağı kaosun oluşturduğu, karamsar gelecek tablolarının kurgulandığı distopyalar geçmektedir. Böylece gözetim toplumu korkuları, distopik gelecek kurgularının yaygınlaşmasına neden olmuştur (Başaran, 2007). 19.yy sosyal ütopyacılarının yerini, 20.yy' da Aldous Huxley, George Orwell, Ursula LeGuin, Arthur C. Clarke gibi edebiyatçılar alarak, distopik kurgularıyla gelecek öngörülerinde bulunmuşlardır.

\section{YAZINSAL ÜTOPYALARIN SOMUTLAŞMA EĞiLIMI}

Edebiyat alanındaki yazınsal ütopyaları somutlaştırılma eğilimi, mimarlıkta, kent tasarımları ve yaşam modülleri ile gerçeğe uyarlanmaya çalışılmıştır. Endüstri devrimi sonrası gelişen bu yaklaşım ile kent tasvirleri yapılırken; çözüm önerilerini komünal yaşamın yerleştirildiği, kentsel mekânlar üzerinden yapmışlardır. Mimarlık aracılığıyla ütopya söylemi, yazınsalıktan çıkarak, bulunulan zaman ve mekân içerisinde, ortaya atılan kent tasarımlarında somutlaşmaya evrilmiştir.

19.yy'da Tony Garnier'ın Uné Cite Industriele'si, Charles Fourier'in Phalanstére'si, Ebenezer Howard'ın Bahçeşehir'i, Jean Baptiste Andre Godin'in Familistere de Guise, Robert Owen'ın New Harmony'si gibi projeler öne çıkan ütopik çalışmalardır (Mumford, 2007; Engels, 2008) (Resim 1). Farklı formları, ayırt edici özellikleri olmakla beraber genel olarak endüstri kentlerindeki işçilerin, fiziksel ve ruhsal ihtiyaçlarının sağlıklı şekilde karşılanamadığını düşünen bu ütopyacılar; 
barınma, beslenme, eğitim ve sağlık ihtiyaçlarının temel alındığı, komünal yaşam prensipleriyle, doğayla bütünleşik, hijyenik, ısıtma ve havalandırma sisteminin yeterli olduğu, konut modülleri ve sosyal tesislerden oluşan kent üniteleri planlamışlardır. Yazınsal bir hayal olan ideal düzenin, somutlaşabilme ihtimaliyle yapılan çalışmalar, ütopik tasarımların devamlılığında itici güç olmuştur.

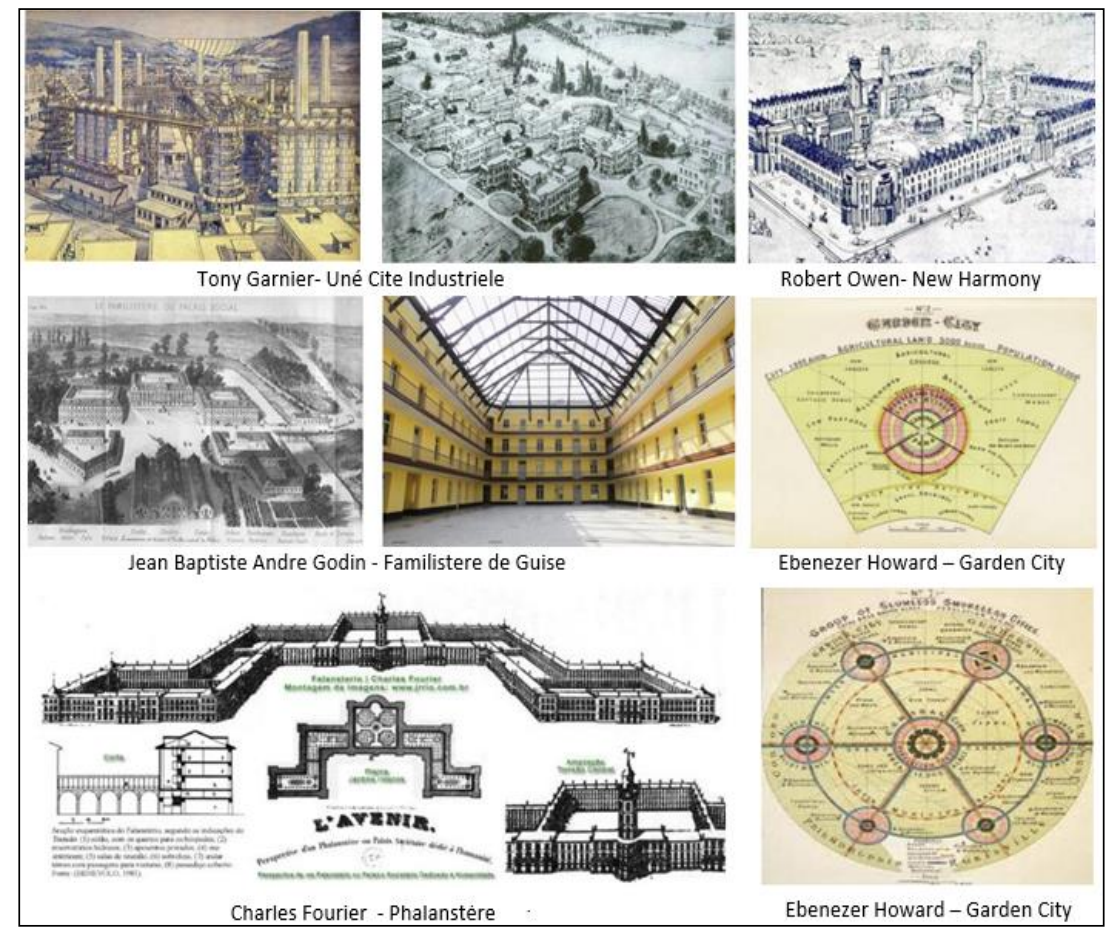

Resim 1. 19.yy Mimarlık Ütopyaları (Hacıhasanoğlu- 2013)

Yazınsal olan "ideal yeri" somutlaştırma çabası, 20.yy'da da devam etmiştir. 20.yy'ın ilk yarısında, otomobil endüstrisinin gelişmesiyle başlayan trafik sorunu ve yapım teknolojilerinin gelişmesiyle gökdelenlerin inşası yeni hareketlerin oluşumunu tetiklemiştir. Bu dönemde, Antonio Sant'Elia'nın fütürist manifestosu, Georgy Krutikov'un The Flying City'si gibi konstrüktivist Rus yaklaşımı, Bauhaus Ekolü ve Manifestosu, Kibbutz'un Kibbutz'u, Frank Lloyd 
Wright'ın Broadacre City'si, Buckminister Fuller'in Dymaxion House'ı ve Le Corbusier'in Plan Voisin'i gibi gelenekseli terkeden modernist yaklaşımlı ütopik fikir ve tasarımlar yer etmiştir (Mumford,2007; Ülker, 2011; Hacıhasanoğlu, 2013). Modern yaşama fikrinin benimsetilmek istendiği ideal yerde, yeni seri üretim teknolojileriyle beraber geleceğin kentleri, kenti oluşturan kamusal açık alanlar, ulaşım aksları ve farklı işlevlerdeki binalar; işlevsellik, örgütlülük, bütünlük ve sadelik ilkeleriyle tasarlanmışlardır (Mumford, 2007). Düşeyde gelişen, çevre yolu ağı bulunan, minimum zemin kullanımıyla maksimum yeşil alanı hedefleyen bu planlamalarda sosyal, eşitlikçi ve teknolojik tasarım anlayışı vardır. 20.yy'ın ikinci yarısından itibaren ise Japonya'da Metabolizma Grubu ve Helix City, Marine City, Wall City, Nagakin Kapsül Binası gibi tasarımları, Ingiltere'de Archigram Grubu ve Walking City, Livingpod, Blow-out Villiage, Computer City gibi tasarımları, Avrupa'da GIAP Grubu gibi oluşumlar ve ütopik fikirler ortaya çıkmıştır (Hacıhasanoğlu, 2013). Bu dönem ütopyacıları, bilim ve teknolojideki hızlı ilerleme ve iletişimin artması nedeniyle daha esnek ve mobilize tasarımlara yönelerek, "ideal yeri" gelecek tasarımlarında organize etmeye çalışmışlardır (Resim 2).

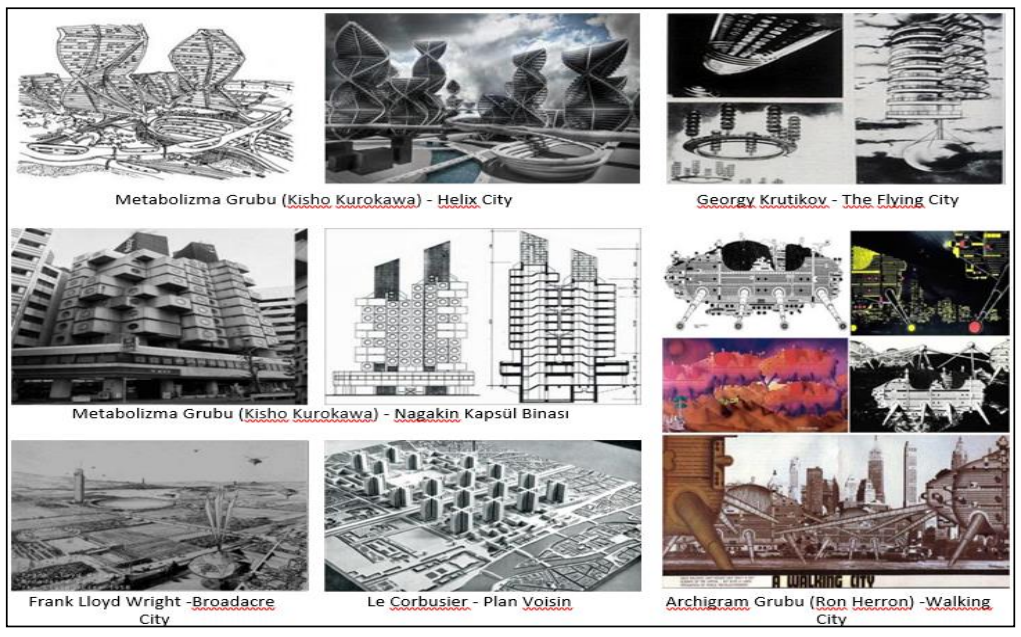

Resim 2. 20.yy Mimarlık Ütopyaları (Hacıhasanoğlu- 2013) 
Ütopyaların Endüstri devrimi sonrasında yazınsallıktan çıkarak, mimarlıktaki yerini almaya başladığından bugüne, sürekli olarak dönemin sorunlarını çözme ve geleceğin tasarımlarını, gelişen teknolojilerin sunduğu olanaklardan faydalanarak, somutlaştırmaya çalışıldığı söylenebilir. Gelecek tasarımları ideali yaratma gayesiyle şekillenirken "dönem sorunlarının" bir bütünlük içerisinde analiz edilmesi gerekmektedir. Yine bu sorunlara getirilen önerilerin deneyimlenmesi de mekânların oluşumlarını ideale yakınlaştırabilir. Bu nokta da sınırsız bir deneyimleme ve eleştiri kültürü barındıran sinema sanatı mimarlığa katkıda bulunabilir.

20.yy başlarında sinemanın keşfiyle ütopyalar yalnızca mimaride değil filmlerde de somut yansımalarla yer etmiştir. Eleştirel ve çözümleyici olan ütopyalar, sinema da geleceğe dair olasılıkların işlendiği bilim kurgu türündeki filmlerde yer almıştır. 20.yy'da dünya ülkeleri arasında yaşanan olumsuz gelişmeler ile edebiyatta ütopyalar yerini distopyalara bıraktı̆ıından, bilimkurgu türündeki filmlerin kaynağı olan bilimkurgu edebiyatının, distopik gelecek kurguları yer almıştır. Bu dönemde öne çıkan Fritz Lang, Ridley Scott, Stanley Kubrick, Jean-Luc Godard, Terry Gilliam, Steven Spielberg gibi yönetmenlerin filmlerinde, sıkıkla distopik gelecek kurgularının işlendiği görülmektedir. Bu filmlerde, distopik gelecek tasvirleri için kullanılan mekânların, mimarlık ütopyalarından esinlenerek, tasarlandığı söylenebilir. Distopik gelecek kurgularında, mimari öğeler fikirsel temsiliyet aracı olarak kullanılmışır. Yönetmen, senarist ve yapım tasarımcıları gibi mekân tasarımının belirleyici aktörleri, var olan fütüristik mimarlık ütopyalarını yorumlamış, geleceğin mekânlarını kurgulamışlardır. Ken Adam, Robert Boyle ve Lawrence G. Paull gibi yapım tasarımcıları, tasarım eğitimi alarak, Fritz Lang, Stanley Kubrick gibi yönetmenler de, dönemin mimarları ile ortak çalışma yürüterek, mekân kurgusu oluşturmaya çalışmışlardır (LoBrutto, 1992; Neumann, 2000; Türeli, 2001). 
Genel olarak yazınsaldan çıkıp mimarlık ile somutlaştırılmaya çalışılan ütopyaların, sinema da sistematik görselleştirmesinin sıklıkla yapıldığı ve gelecek öngörülerinin bilimkurgu türünde yer ettiği görülmektedir. Mekân yaratım süreci ile oluşan mimarlık ve sinema arasındaki ilişkinin distopik gelecek kesişimlerini ve sonuçlarını filmler üzerinden irdeleyebilmek için bilimkurgu filmlerinin tarihsel gelişim sürecine değinmek faydalı olacaktır.

\section{GELECEK ÖNGÖRÜLERINDE SISTEMATiK GÖRSELLEŞTIRME - BiLIMKURGU FiLMLERi}

Robert A. Heinlein bilimkurguyu "geçmiş ve günümüze ait dünya bilgisine dayanarak bilimsel yöntemler ışığında geleceğin olayları üzerine yapılan gerçekçi tahminler" olarak tanımlar (Başaran, 2007). Ancak bu "gerçekçi" tahminlere bakıldığında baskın olarak ütopik düşüncelerin de yer aldığını görülmektedir.

Bilimkurgu sinemasına kaynaklık eden bilimkurgu yazını; 18.yy'da aydınlanma çağı ile başlayarak, bilimsel ve teknolojik buluşları konu ederek gelişmiştir. Mary Shelley'in Frankenstein'ı ile başlayan dönemin, öne çıkan diğer isimleri, teknofili ve teknofobi gibi iki zıt yaklaşımı savunan Jules Verne ve H.G. Wells'tir (Başaran, 2007; Reyhanoğulları, 2012; Erol, 2013). Daha sonra 1895'de Lumiere Kardeşler tarafından icat edilen sinematografın, sinema devrini başlatmasıyla bilimkurgu yazını filmlere girmiştir. George Melies'in Le Voyage dans la Lune (Ay'a Seyahat) filmi ile başlayan bilimkurgu türü, Fritz Lang'in Manhattan gökdelenlerinden etkilenerek çektiği 1927 yapımı Metropolis filmi ile değer kazanır. Bu dönemle beraber başlayan bilimkurgu türü filmler, dönemlerinin yaşanan siyasi gelişmelerini (dünya savaşı ve soğuk savaş, kültürel devrim, 68 olayları vb.), nükleer ve uzay teknolojilerindeki ilerleme yarışını (Sputnik vb.) ve sonuçlarını konu eder ve gelecek öngörüleri önem kazanır (Akşit, 2012; Erol,2013; Monaco, 2011). 1970'lerde mikroişlemcilerin keşfi ile başlayan sanal teknolojilerin gelişimi; genetik ve robotik teknolojilerinin de gelişimini hızlandırır. Yapay, zeka, sanal 
gerçeklik, bürokratik ve otoriter güçlerin kaosu, ekoloji ve nüfus dengesizlikleri, salgın ve uzay temalı bilimkurgu filmleri, distopik kurgularıyla yaygınlaşır. 2000'li yıllarla beraber bilimkurgu temaları, sanal gerçeklikten modern bilim kuramlarına (paralel evrenler, karadelikler, solucan delikleri, kuantum fiziği, genetik teknolojileri, klonlama), zaman ve uzay yolculuklarından, kapitalizm vb. sistem eleştirilerine kadar geniş bir yelpaze sunarak, distopik gelecek tasvirlerini aktarır (Özen, 2006; Akşit, 2012; Erol,2013). Frankenstein (1931- James Whale), Forbidden Planet (1956- Fred M. Wilcox), Alphaville (1965- Jean-Luc Godard), A space time Odyssey (1968-Stenley Kubrick), Solaris (1972-Andrey Tarkovski), Blade Runner (1982-Ridley Scott), Brazil (1985-Terry Gilliam), EXistenZ (1999David Cronoberg), Minority Report (2002-Steven Spielberg), The Island (2005Micheal Bay), Moon (2009-Duncan Jones), Cloud Atlas(2012-Tom Tykwer, Andy\&Lana Wachowski) ve Interstealler (2014-Christopher Nolan) gibi filmler dönemlerinin gelişmelerini ve gelecek kurgularını yansıtan örnekler arasında yer almaktadır.

Çıkış noktası edebiyat ürünleri olan ütopyalar, mimarlık ile nesnelleşme eğilimi göstermiş, sinemada bilimkurgu filmleri ile sistematik olarak görselleştirilmiştir. Gerçek ve kurgusal mekânların kullanımında yararlanılan mimari öğeler kimi zaman temsiliyet aracı, kimi zaman fon olarak kullanılmıştır (Kaçmaz, 2001; Gülüş, 2006; İnce, 2007; Ergin, 2007; Sayar Güntan, 2007; Tüzün, 2008; Sarı, 2010; Tunçok, 2010; Allmer, 2010; Monaco, 2011). Görselleşen ütopyaların, mekân kurguları ise distopik mekânlar ile sağlanmıştır. Bu mekânların yaratım süreci, mimarlık ile etkileşimli olarak gerçekleşmiş, tasarlanan kent ve kent unsurları, geleceğin mekânları hakkında öngörüler oluşturmuştur. Mekân yaratım sürecinin aktörleri; yönetmenler, senaristler, tasarım eğitimi almış yapım tasarımcıları, mimarlar ve modern mimarlık akımlarının temsili unsurları olmuştur. 
Etkilenilen ya da doğrudan kullanıma dâhil edilen mimari unsurları, örnekler üzerinden incelemek, mimarlığa sunduğu ya da sunabileceği katkıları tespit edebilmek için faydalı olacaktır. Bu nedenle bilimkurgu filmlerinin mekândan bağımsız düşünülemeyen distopyalarına ait tasvirleri incelemek için okunan filmler Metropolis (1927), A Clockwork Orange (1971), Cloud Atlas (2012) olarak belirlenmiştir. Mimari temsillerin/metaforların yoğun olarak kullanıldığı bilimkurgu filmlerinden yapılan seçilimde; distopik mekân kurgularının başlangıcı kabul edilen ve döneminin fütürist yaklaşımları ve yönetmeninin yeni yapım tekniklerinden etkilenmesi ile oluşturduğu, Metropolis (1927) filmi, II. Dünya savaşı, 68 Haretketleri, Soğuk Savaşı Dönemi, uzay yarışları, ekonomik buhranlar, sosyalizm ve kapitalizm arasında dünya devletlerini yönlendiren çekişmelerin yaşandığı kaos ortamının oluşturduğu paranoya toplumunun bir yansımasını ve modernist yaklaşımlarla tasarlanan mekânları içeren, hem görsel hem yazınsal bir eser olan A Clockwork Orange (1971) filmi, Mikroişlemcilerden, bilgisayarlara, internetin yaygınlaşmasından, robotik alanındaki bir çok gelişmenin yaşandığı, modernizmin çöküşe geçtiği ve post-modernizmin temellenerek geliştiği 80’ler ve sonrasının yansıtıldığı bilimkurgu filmlerinin, distopik kurgulardan, birkaçını (apocaliptik, totaliter, bürokratik, cyberpunk) bir arada işleyen ve yakın zamanda yapımı tamamlandığından günümüz teknolojilerinin de mekâna yansımalarının incelebileceği güncel bir örneği olan Cloud Atlas (2012) filmi, mimari algı açısından önemli olduğu düşünülerek, okunmaya çalışılmıştır.

\section{1. Örnek Film Okumaları Üzerinden Değerlendirme}

Metropolis 1927 - Fritz Lang, New York kentinde yükselen çok katlı yapıların siluetinden etkilenerek, Alman Ekspresyonizminin eserleri arası giren Metropolis filmini, 1926 'da çekmiştir. Mimarlık eğitimi almış olan Lang, filmin yapımında, Le Corbusier'in şehir tasarımlarını ve Antonio Sant Elia'nın Citta Nuova'sını incelemiştir (Ertem, 2010). 2026 yılında geçen filmde; gökdelenler ile donatılmış 
kentin distopik kurgusu, sinema tarihinde sonraki bilim kurgu filmleri için simge olmuştur. Derin ekonomik farklılıkların oluşturduğu iki sınıfın çatışmasını konu eden filmde yer altında ve yer üstünde iki farklı şehir kurgulanmıştır. Proleter sınıf, yer altında makinelerle, sermaye sahipleri ve yöneticilerden oluşan kısım ise yer üstünde yaşamaktadır (Resim 3).

Yeraltı şehri gri tonları, dumanlı havası ve keskin rasyonel çizgileri ile bir makineyi andırmaktadır. Bu makine şehirde yaşayanların özel alanı tek tip lojman konutlarıdır. Konutları çalışma alanına bağlayan tüneller, basık ve karanlık atmosferiyle, bir cezaevi koridorlarını andırmaktadır. Bu koridorlar, taşıtlar olmadığından, yaya sirkülasyonunun ulaşım ağıdır. Geçiş koridorları, işçilerin makinelerin sürekliliğinden sorumlu oldukları çalışma mekânına bağlamaktadır. Modernizmin sadelik ve monotonluğunun eleştirisi gibi görülebilen, makine kentin sakinleri de tektip görünümleri ve umutsuz yaşamları ile üst sınıfın refahı için sürekli bir devinim içerisindedirler (Resim 3). Sosyal mekânlar bulunmazken ibadet mekânının olması denetim mekanizmasının temsili göstergesidir. Yerüstünde yaşayanların mekânları ise makine kentin tersi bir görünümdedir.

Düşeyde gelişen yerüstü kentinin sakinleri, yer yer farklılıklar gösteren, cam ve çelikten tasarlanmış, keskin geometrik formlardaki megastrüktürlerde yaşamaktadırlar. Burada yaşayanların, alt katmandan farklı olarak araç kullanımı olduğundan gelişmiş bir ulaşım ağı mevcuttur. Uçabilen araçların da yer aldığı bu ulaşım ağının, birkaç katmandan oluştuğu görülmektedir (Resim 3).

Düşeyde gelişim gösteren yapılar arasında, yüksekte devam eden otoyollar mimarlık ütopyalarının bir açıdan yansıması gibi okunabilir. Üst katmandaki kentin yöneticileri için Babil Kulesi metaforuyla diğer binalardan ayırt edici ihtişamla farklılık gösteren merkez yapısı bulunmaktadır. Yer üstünde yaşayanların sosyal alanları mevcuttur. İnsanlar açık yeşil alanlarda eğlenirken görülmektedir. Genel hatları ile modern ve fütüristik kent imajı veren üst katman 
ile işlevsel, tektip modüllerden oluşan, karanlık alt katmanın görünümüyle distopik mekân kurgusuna sahip olan Metropolis sonraki bilim kurgu filmlerinin teknolojik kentlerine altlık oluşturmuştur.

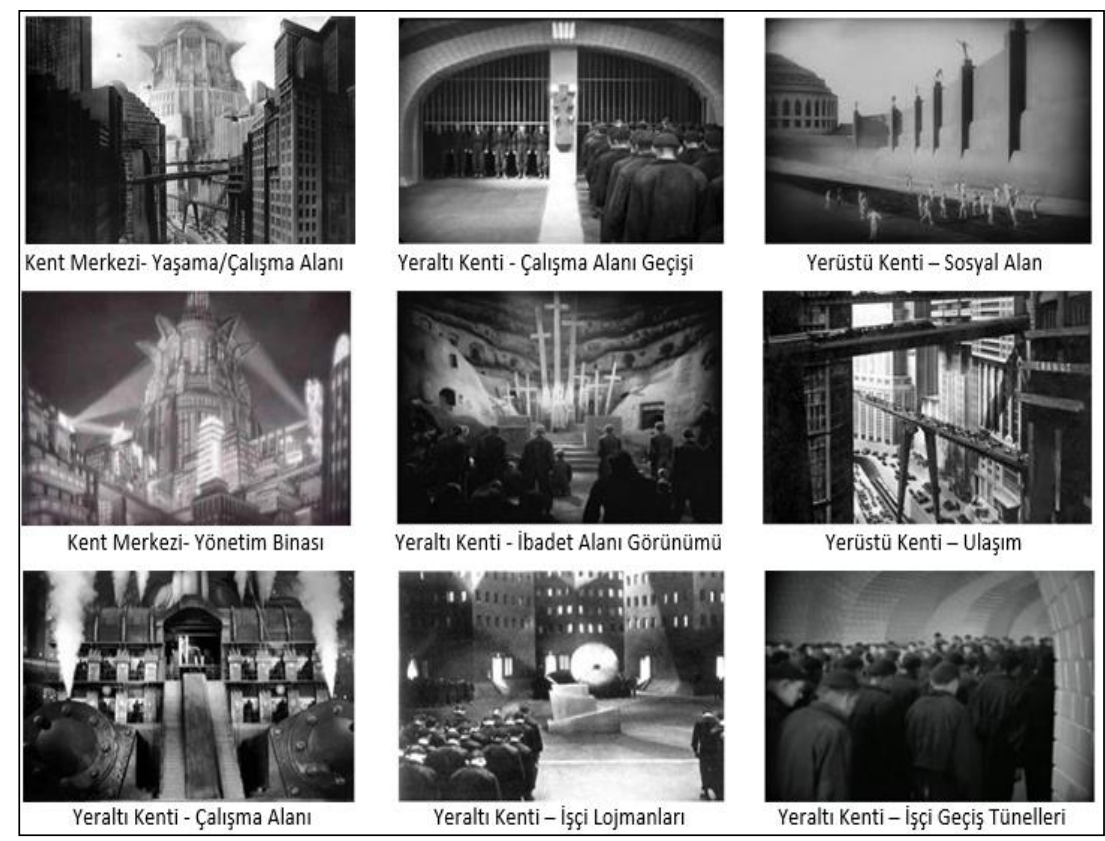

Resim 3. Metropolis Filmi- Kentten Görünümler-(Boake 2007 ve Film Kareleri)

A Clockwork Orange 1971 - Anthony Burgess'in aynı adlı yapıtından uyarlanan 1971 yapımı Amerikan filmidir. Filmin yönetmeni Stanley Kubrick'tir. Film geleceğin İngiltere'sinde bir grup gencin şiddet eğilimlerini ve otorite kurumlarının bu sorunlara getirdiği çözümler, distopik bir kurguyla anlatmaktadır.

Distopik kurgu bu filmde, mekânların işlev değişiklikleri ve abartılı düzenlemelerine zıt duran insan ilişkileri ile yaratılmıştır. Film boyunca; gençlerinin kullandığı sosyal alanlar, farklı ekonomik sınıftaki insanların yaşam alanları ve sağıı merkezi gösterilmekte ve bu mekânların farklılaşan misyonları anlatılmaktadır. Misyon değişikliklerinin belirgin olduğu alanlar sosyal 
mekânlardır. Gençlerin kullandığı bu sosyal mekânlardan öne çıkanlar; renkli kadın figürlerinin ve müstehcen içki ekipmanlarının kullanıldığı şiddet karargâhı misyonunda "eğlence mekânı" olan bir bar, alışveriş mekânları ve çeteler arası çatışmaların yaşandığı eski bir tiyatrodur. Siyah perdelerle kaplı duvarlar, beyaz vücutlu, renkli peruklu kadın figürlü sehpalar ve içecek makinelerinin bulunduğu Korova Milk Bar modernist bir mekânda, masumiyet ve suç/şiddet tezatlığını simgelemektedir. Mekân işlevinin dışına taşınarak yeni anlama bürünmüştür (Resim4). Şiddetin yansıtıldığı, misyonunun dışına çıkartılan başka bir mekânda eski bir sanat yapısı olan tiyatro salonudur. Gösterilen tiyatro salonunun sahnesi, mekân kullanımı olarak; yaratılan distopik dünyanın şiddet ve tecavüz olaylarının, müzikal atmosferle yansıtıldığı bir yerdir. Sosyal mekânlardan bir diğeri ise yoğun sıcak renklerin kullanıldığı, yapay aydınlatmaların yer aldığı ve birbirini tanımayan gençlerin iletişime geçtiği gösterişli alışveriş pasajıdır. Film de brüt ve masif kütlesi ile donuk ve sert bir simge olan, şiddete eğilimli kişilerin "ıslah" edildiği sağ|ık merkezinin amfisi de seminer alanı olmaktan çıkartılarak psikolojik işkence laboratuvarı olarak gösterilmektedir.

Farklı ekonomik sınıfa mensup olmalarına rağmen konutlarda kullanılan, donatı elemanlarından, sanatsal aksesuarlara, mekân bölünmelerinden, kaplama malzemelerine kadar sunulan seçimler, sıcak renklerde ve fütürist tasarımlarla gösterilmektedir (Resim 4). Filmde kurgu, klasik distopyaların, gri tonları ve karmaşık ulaşım sistemleri, katmanlaşan yaşam alanları ve kirli bir kent görünümden uzaktır. Burada sıcak renklerin kullanıldığı ve modernist mekânların işlevlerinin farklılaşması, mekânın uğradığı anlam kaymasıyla yaratılan, distopik bir kurgu sunulmaktadır. 


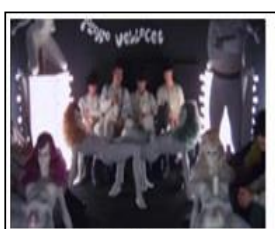

Korova Milk Bar
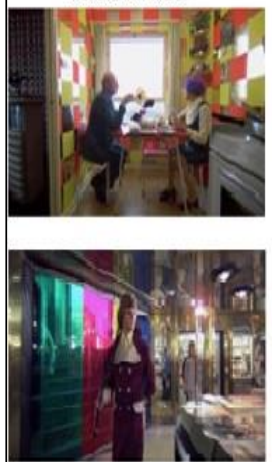

Alışveriș Pasajı

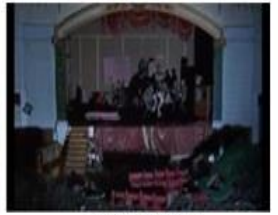

Tiyatro Sahnesi

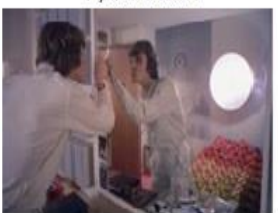

Alt sınif konutundan görünümler

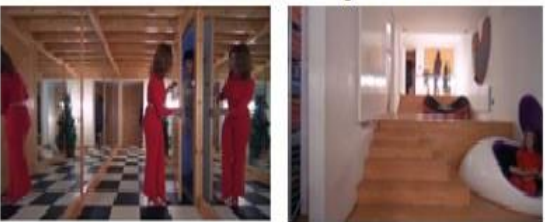

Üst sınıf konutundan görünümler

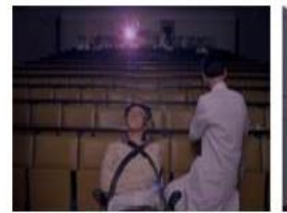

Sağ|lk Merkezi Amfisi

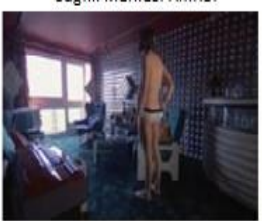
Sağlık Merkezi Binası
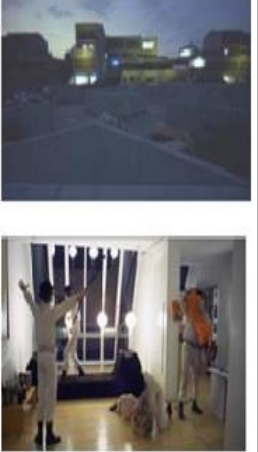

Resim 4. A Clockwork Orange Filmi- Kentten Görünümler (Film Kareleri)

Cloud Atlas 2012- David Mitchell'ın yazınsal eseri olan Cloud Atlas, Andy Wachowski \& Lana Wachowski, Tom Tykwer yönettiği 2012 yapımı filmdir. Film altı farklı zamanda kurgulanmıştır. Filmin zaman aralığı 1849-2321'dir. Filmde 2144 ve 2321 yılları olmak üzere iki farklı döneme ait distopik gelecek kurgularını gösterilmektedir. 2144'ün Neo Seul'unun cyberpunk distopyası ve 2321'in dünyasının post-apokaliptik distopyası anlatılmaktadır. 2321 yılının distopyası, post-apokaliptik bir tür olduğundan; kıyamet sonrası dünyada, insanlar ilk yerleşik düzene geçmiş gibi yaşamakta çadır, enkaz ve baraka tarzı mekânlarda, barınmaya yönelik ihtiyaçlarını karşıladıklarından, mimari mekânlardan çok doğal çevre ön planda gösterilmektedir. Bu nedenle cyberpunk distopyasının mekânlarını incelemek, gelecek öngörülerini analiz etmeyi kolaylaştıracaktır. Kenti oluşturan diğer bir öğe ulaşım sistemidir. Düşeyde büyüyen kentler de ulaşım binalar arasında uçan taşıtlarla gerçekleştirilmiştir. Ulaşımın teknolojik gelişmelere paralel olan yapısı, değişimleri yansıtmaktadır. Kentte binalar arasında bulunan yüksek köprüler, ulaşım aksının bir parçasıyken, eski yollar 
konumundadır (Resim 5). Yeni ulaşım aksı ise inşa edilmemiş, sınırlandırılmış yol simülasyonlarıdır. Bu yeni ulaşım aksı, manyetik bir alan gibi görünmekte, yatayda ve düşeyde hareket edebilen araçlar bir akstan diğerine geçebilmektedir (Resim 5). Üst katmanlarda hareket eden uçaklar ve arabalar, bina içlerinde veya aralarında bulunan boş alanlara park etmektedirler. Diğer bir ulaşım detayı da yükselen suların içerisinde cam ve çelikten devam eden tünellerdir.

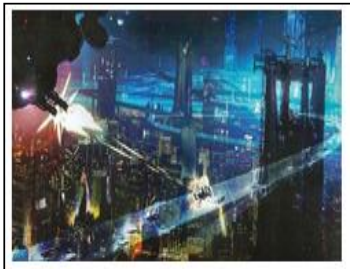

Kentten Görünüm

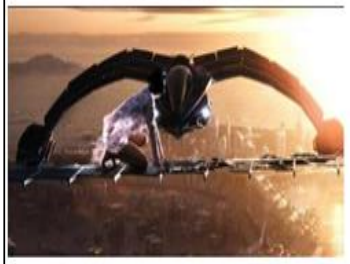

Uçan Polis Araçları

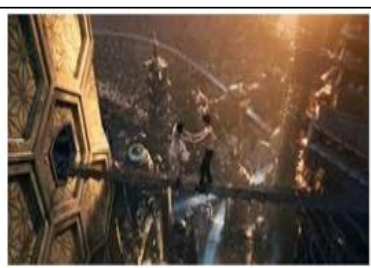

Kentten Görünüm

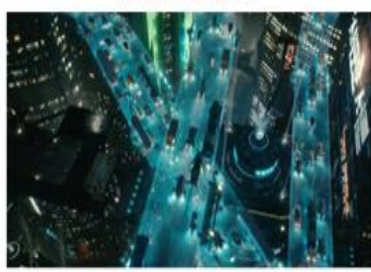

Ulaşım Sistemi

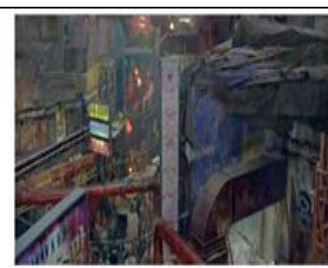

Kentin Alt Katmanından Görünüm

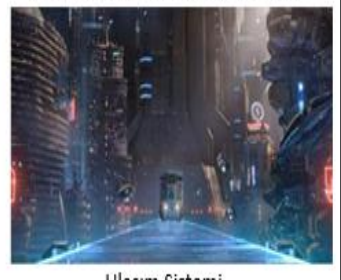

Ulaşım Sistemi

Resim 5. Cloud Atlas Filmi- Kentten Görünümler (Film Kareleri)

Film de 2144'ün cyberpunk distopyası; eski Seul'un çoğunun sular altında kalmasından sonra kurgulanmış Neo Seul'de gösterilmektedir. Neo Seul kenti; ileri teknoloji olanaklarına sahip ancak sınıf ayrılıklarının yoğun olduğu, düşeyde katmanlaşmış yapısı, soğuk ve karanlık tonları ile sunulmaktadır.

Kent yapılarının sürekli düşeyde yükselmesi ile hiyerarşik sisteme göre katmanlaşan yaşam mekânları, klasik distopik dünyanın imgeleri olarak kullanılmıştır (Resim 5). Uçan sivil ve askeri araçlar üst katmanlar devam ederken, alt katmanlar da yaşayanların ise daha çok sokak kültüründe, yaya olarak ulaşımı sağladıkları görülmektedir (Resim 5). Üst katmanlar; yöneticilerin ve sermaye sahiplerinin yaşama ve çalışma mekânları ile klon işçilerin imal edildiği 
fabrikalardan oluşmaktadır. Çelik konstrüksiyonlu bu yapıların cepheleri; masif çelik görünümü ve mega reklam panolarıyla kasvetli ve karanlık bir dünyanın görünümünü sunmaktadır. Üst katmanlarda, klon işçi üreten fabrikaların görünümü endüstri döneminin karanlık hangar tipi mekânları andırmaktadır (Resim 6). Bilimsel çalışma alanlarının, alışılagelen algıdaki büyük, hijyenik, kompleks işlevli ve güvenlikli laboratuvarların yerini seri üretim yapan fabrikalara almaktadır. Fabrikaların içerisinde bulunan biyotanklarda üretilen android robotların itaatkarlığına sahip klon insan-işçiler, imal edilerek üst sınıf insanların hizmetine gönderilmekte, belli süre sonra tekrar toplanıp, geri dönüşüm alanlarına getirilerek eritilip, işleme sokulmaktadırlar (Resim 6). İşlem neticesinde çıkan ürünler, yeni klonların besin kaynağı olduğundan, üretim-tüketim ilişkisi sürekli bir dengede tutulmaktadır. Yine bu işçiler, üst tabaka kişilerinin ve işletme sahiplerinin yanında kapsüllerde kaldığından, ayrı bir yaşama mekânlarına gerek kalmadığı gösterilmektedir.

Distopik kent vurgusu, şehrin alt katmanlarının dar ve kirli hücreleri ve büyük, penceresiz, soğuk renklerin hâkim olduğu yapıların görünümü ile arttırılmıştır. Alt katmanlar yaşayanlar, sahip oldukları uzak doğu kültürünü yaşam alanlarına yansıtan alt sınıf yerliler, göçmenler ve isyancılardan oluşmaktadır. Üst katmanlarda olmayan sokak oluşumları, bu sokaklarda ki açık yeme-içme mekânları ve barınma mekânları kültürlerinin devamlıığının simgeleridir. Alt katmanlarda yaşayan bireylerin konutlarında da iç mekân düzenlemeleri için sanal gerçeklik sağlayan farklı otomasyon sistemleri olduğu gösterilmektedir. Burada ki kullanıcılarda, duvarları, yerleri, donatı elemanlarını, pencereleri kendisi seçmektedir (Resim 6). Bu seçimlerde kullanıcılara özgürlük, sınırsızlık ve her an değişebilirlik sağlandığı görülmektedir. İç mimari tasarımlar, grafik programları ile sağlanmıştır. 


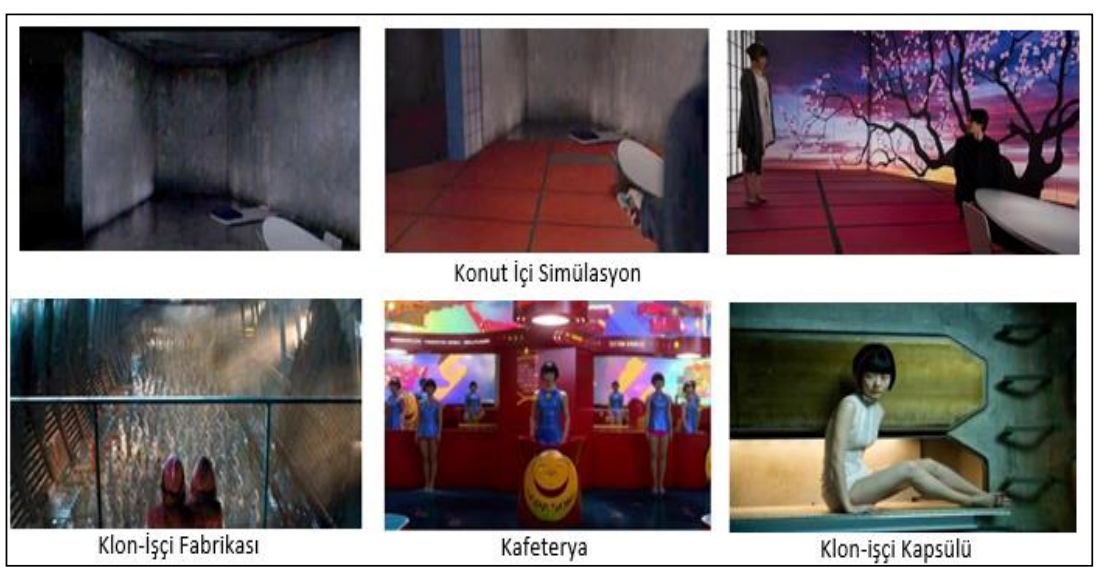

Resim 6. Cloud Atlas Filmi- Mekânsal Görünümler (Film Kareleri)

Filmde diğer çarpıcı nokta mekân içi düzenlemelerdir. Üst katmanlarda yaşayanların sosyal mekânlarında bu durum ön plana çıkmaktadır. Kullanım alanlarının görünümleri sanal gerçeklik sağlayan simülasyonlar ile farklılaşmaktadır. Oturma gruplarından, yiyecek-içecek hazırlama makinelerine, duvar-döşeme-tavan gibi sabit yapı elemanlarının kaplamalarına kadar her şey bir kumanda paneli ile değiştirilebilmekledir. Brüt ve karanlık görünen tüm yüzeyler, yapılan görüntü seçimiyle değiştirilmektedir. Klon işçiler sürekli olarak mekân içerisindeki kapsüllerde tutulmaktadır. Günümüzde konutlarda yaşama alanlarını oluştururken varsayılan odak noktalarının olmadığı görülmektedir. Yaşama mekânın şekillenmesinde rol oynayan televizyon gibi elektronik eşya kullanımı bulunmamaktadır. Televizyon, telefon ve bilgisayarların yerini hologramlar almıştır. Açıldığında şeffaf bir sınırlandırıcı üzerine görüntülerin ve bilgilerin yansıdığını gösterilmektedir. Genel olarak Cloud Atlas filminde, mekânların kullanım şekli; sosyal farklılıkları, hiyerarşiyi, yaşama şekillerini, teknolojik ve bilimsel gelişmeleri temsil ettiği distopik bir kurgu gösterilmiştir. 


\section{TARTIŞMA ve SONUÇ}

Sosyal ve bireysel tepki olarak tanımlanabilen "Ideal düzen" fikri yazınsal alanda ilk ürünlerini kurgulayarak, ütopya kavramını oluşturmuştur. Yazınsal alanda kimliğini kazanan ütopyalar; kurgularını hedeflediği ideal düzen için gereken coğrafi yer ve bu yeri şekillendiren mimari unsurlar ile bağ içerisindedir. Üretim ve tüketim dengelerinin değişmesi ile toplumların yaşam tarzlarında yaşanan radikal değişimin sorunlarına çözüm önererek ortaya çıkan mimarlık ütopyaları; yazınsal olanı, düşünüleni/arzu edileni somutlaştırmaya çalışmıştır.

Son yıllarda disiplinler arası çalışmalar ön plana çıkmakta ve araştırmalar derinleşmektedir. Bu çalışmanın amacı da disiplinler arası ortak paydaya sahip olan mekân ve insan kesitinde ideali arama arzusu serüvenine bütüncül bir bakış açısı sunmaktır. Yazınsal olan ütopyalardan, görsel olan distopyalara kadar olan süreçte mekân kurgusunun etkisi ile ilgili bütünlüklü bir çerçeve ortaya koymaktır. İdeal düzen arayışına karşın ise aslında ideallerin zamana ve mekâna göre statik olmayan bir yapısı olduğunu vurgulamaktır. Her ideal ye ister yazınsal ister görsel olarak kurgulanmış olsun bir sonraki dönemde insanlığın karmaşık ve kaotik yapısı çeşitlenen fikir ve hayalleri doğrultusunda beğenildiği kadar eleştiri odağı da olmaktadır. Bu çalışma ile; ortak payda da buluşabilmek ve şartları iyileştirmek ve/veya sistemi eleştirmek amacıyla ortaya çıkan ütopyaların; üretenin ister birey ister kitle olarak algısı/beklentisi/hayal gücü ile şekillendiğinden distopyalara doğru evrildiği ya da sonrasında yöneltilen eleştiriler ile distopik özelliklere de sahip olduğu ortaya çıktığı ve mekân yaratımı ile aktarıldığı söylenebilir.

Edebiyat tasvirlerinde kullanılan mimari unsurların çözüm sürecine etki eden ütopyaların; bir sanat olarak ortaya çıkışı ile beraber sinema da görselleştirilmesi, görselleştirmelerin sistematikleşmesine olanak tanımıştır. Edebiyat tasvirlerinde kullanılan mimarlık, mekân yaratımları ile sinema filmlerinin kurgusuna etki etmiştir. Sinemada, gerçek ve kurgusal mekânların kullanımında yararlanılan 
mimari öğeler kimi zaman temsiliyet aracı, kimi zaman fon kimi zamanda yüklenen metaforlar ve imgelerle sosyal anlatım aracı olarak kullanıldığından, bilimkurgu filmlerinde; ütopik dünya tasvirlerinin yaratımı bu kullanım şekilleri ile oluşturulmuştur. Bilimkurgunun gelişimiyle gelecek öngörülerini ele alan filmler, yazınsal ve mimari ütopyalardan etkilenmişlerdir. Gelecek tasvirlerine yönelik ütopik fikirler, bilimkurgu filmlerine; var olan mimari akım ve tasarımlardan esinlenilip, yapım sürecindeki aktörlerin hayal gücü ile birleştirilerek yansımıştır. Ütopyalardan, bilim ve teknolojinin getirdikleriyle beslenen bilimkurgu edebiyatının sistematik olarak görselleşmesi, toplumsal sorunlara ve sistemlere sunduğu eleştirel bakış açısı yaygınlaştıkça distopik kentler öne çıkmıştır. Distopik kurgularda yer alan, mimari ürünlerden ve fikirlerden esinlenmeler, bilimkurguda yer edinmiş ve sinemada deneyimlenme imkânı bulan mimari mekânlar yeni bir sürece girmiştir. Çalışma kapsamında incelenen örnekler göstermiştir ki dönemin mimarlık ütopyaları bilimkurgu filmlerinde yer almaktadır. Görselleşen ve deneyimlenen distopik mekânlar, toplumda yaratılmak istenen algı ve bilinci yönlendirmede temsiliyet aracı olarak kullanılmıştır. Ütopyaların 20.yy ve sonrasında distopyalara dönüşmüş ve bir önceki ütopyaların ideal olduğu fikri eleştirilmiştir. Yaşanan savaşlar, ekonomik buhranlar, devletler arası güç yarışları, sömürge faaliyetleri ve küresel ısınma gibi doğal dengenin bozulması, enerji kaynaklarının tükenme riski gibi süreçlerin, toplumlarda yarattığı travma ve zorlu yaşam koşullarına eleştirel tepkileri içeren sinema, mimarlık ve edebiyat kendi ütopyalarını kullandıkları "dil” ile yaratmışlardır. Günümüzde, bu süreçleri değerlendiren tasarımcılar tarafından daha iyi bir dünya için ortaya atılan ekolojik kent önerileri, enerjisini üreten akıllı binalar, kendini yenileyen malzemeler, deneysel aşama da kalsa da genetik mimarlık fikri, teknolojinin esnek ve sınırsız kullanım imkanları sunduğu hiperuzay mimarlığı, distopyaların gerçekleşmemesi, ideal ortamı yaratabilme kaygısı ve öngörüsü ile ilerletilen farklı mimarlık yaklaşımlarının çalışmalarıdır. Günümüzde birer ütopya olarak 
değerlendirilebilen; genetik mimarlık ve siberuzay mimarlığı gibi yaklaşımlar, teknolojinin geldiği nokta/geçirdiği süreç ve insanoğlunun zihinsel evrimi düşünüldüğünde şu an bilimkurgu olarak hayal ettiğimiz dünya bize çok uzak görünmemektedir. Edebiyat, sinema ve mimarlıkta üretim aktörleri ile yansıtılan fikirlerin uygulanabilirliği ancak tüketimin aktörlerinin etkinliği ile mümkün olabilir. Toplumsal algının yönlendirilmesi, fikirlerin yaygınlaşması ve karamsar gelecek tablolarının uyarıcılarını dikkate alarak oluşturulacak bilinçlenme ideal düzen fikrine yakınlaşma sağlayabilir. Son söz olarak, “ideal düzen” fikirleri her ne kadar ütopik/distopik olarak ortaya çıksa/şekillense de yazınsaldan görsel somutlaştırmaya kadar; her ütopya, ulaşabilirliğine dair kendi hayalini yaşatmakta, bulunulan çağın dinamikleri ile yersiz/evrensel/geçici mekânsal düzenlerinin gerçekleşmesi halinde bitmekte ve başka ütopyaları türetmektedir.

Geriye kalan ise bize sunulan geleceğe ne kadar hakimiz ve bilinçli şekilde yönlendirmek için yapabileceklerimiz nelerdir? 
KAYNAKÇA

Akkuş, A, C. (2008). Sinema ve Kent. Yüksek Lisans Tezi, Mimar Sinan Güzel Sanatlar Üniversitesi Fen Bilimleri Enstitüsü, İstanbul.

Akşit,O,O. (2012). Bilimkurgu Sinemasında Teknokültürün Inşası. Doktora Tezi, Ege Üniversitesi Sosyal Bilimler Enstitüsü, İzmir.

Akyıldız, Ö. (2012). Mimari Mekânların, Sinemanın Kurgusal Mekânları Üzerine Etkileri. Yüksek Lisans Tezi, Yıldız Teknik Üniversitesi Fen Bilimleri Enstitüsü, İstanbul.

Allmer, A. (2010). Sinemada Mimarlık, Sinemekân. İstanbul: Varlık Yayınları.

Alvarado, R.G. (2008). Analysis of Filmmaking Techniques for Architectural Animations, ODTÜ Mimarlık Fakültesi Dergisi, 25,2, 133-149.

Alver, K. (2009). Ütopya: Mekân ve Kentin İdeal Formu. Sosyoloji Dergisi, 18, 139154.

Aydın, E, D. (2004). Bilimkurgu Sineması Yapım Tasarımı Sürecinde Bilgisayar Teknolojilerinin Kullanılması. Yüksek Lisans Tezi, Yıldız Teknik Üniversitesi Fen Bilimleri Enstitüsü, İstanbul.

Başaran, T. Y. (2007). Soğuk savaş sonrası bilimkurgu sinemasında distopik sistemler ve kontrol mekânizmaları, Yüksek Lisans Tezi, Ankara Üniversitesi Sosyal Bilimler Enstitüsü, Ankara.

Bayartan, M. (2009). Ütopyalarda Coğrafi Mekân. Sosyoloji Dergisi, 3, 18, 69-95.

Boake, T.M. (2007). Architecture and Film: Experiential Realities and Dystopic Futures. Waterloo University. 27 Aralık 2014 tarihinde Lisankinch veritabanından alınmıştır.

Bozdoğan, M. (2008). Sinema kavram ve tekniklerinin mimari tasarıma etkileri. Yüksek Lisans Tezi, Yıldız Teknik Üniversitesi Fen Bilimleri Enstitüsü, İstanbul.

Canbaz Yumuşak, F. (2012). Ütopya, Karşı-Ütopya ve Türk Edebiyatında Ütopya Geleneği. Bilig, 2, 61, 47-70. 
Doğay Örs, A. (2001). Sinematografi ve Mimarlık. Arredamento Mimarlık, 11, 7379.

Dürüşken, Ç. (2012). Uzaklarda Bir Diyar: Civitas Solisa. Istanbul Üniversitesi Sosyoloji Dergisi, 3,18, 15-24.

Düştegör, P. (2011). Sinema ve Sinema Mekânlarının Tarihsel Gelişimi ve İstanbul Iilinde Yer Alan Sinema Mekânlarının Incelenmesi: Alışveriş Merkezleri Üzerine Değerlendirme Çalışması. Yüksek Lisans Tezi, Yıldız Teknik Üniversitesi Fen Bilimleri Enstitüsü, İstanbul.

Engels, F. (2013). Ütopyadan Bilime Sosyalizm. İstanbul: Evrensel Basım Yayın.

Ergin, S. (2007). Mimarlık Ve Sinema Etkileşiminin Sinemasal Mekâna Etkileri ve Nuri Bilge Ceylan Sinemasından Bir Örnek : "Uzak". Yüksek Lisans Tezi, Anadolu Üniversitesi Fen Bilimleri Enstitüsü, Eskişehir.

Erol, V. (2013). Bilimkurgu Sinemasında Distopya ve Siberpunk Çerçevesinde Dönüşen Gelecek Tasvirleri. Yüksek Lisans Tezi, İstanbul Üniversitesi Sosyal Bilimleri Enstitüsü, İstanbul.

Ertem, Ü. (2010). Sinema ve Mimarlık Etkileşiminin Örnek Kara Filmler Üzerinden Incelenmesi. Yüksek Lisans Tezi, İstanbul Teknik Üniversitesi Fen Bilimleri Enstitüsü, İstanbul.

Gülüş, İ. (2006). Sinemada Görsel Zaman ve Mekân Kurgusu. Yüksek Lisans Tezi, Selçuk Üniversitesi Sosyal Bilimleri Enstitüsü, Konya.

Hacıhasanoğlu, I. (2013). Mimarlık ve Ütopya Ders Notları, İstanbul Teknik Üniversitesi, İstanbul.

İnce, E, T. (2007). Mimarlık Sinema Ilişkisinin Sokak Mekânı Üzerinden Incelenmesi. Yüksek Lisans Tezi, Gazi Üniversitesi Fen Bilimleri Enstitüsü, Ankara.

Kaçmaz, G. (2001). Fellini Sinemasında Mekân ve Mimarlığa İlişkin Temalar, Arredamento Mimarlık, 11, 97-102. 
Kayaarası, T. (2011). Yeni Türk Sinemasında İstanbul Kent Imgeleri. Yüksek Lisans Tezi, İstanbul Kültür Üniversitesi Sosyal Bilimleri Enstitüsü, İstanbul.

Konca, G. (2011). Bir Mitin Iki Ucu: Kent Ve Sinema. Yüksek Lisans Tezi, İstanbul Teknik Üniversitesi Fen Bilimleri Enstitüsü, İstanbul.

Kubrick, S. (Yöneten) (1971) A Clockwork Orange [Sinema Filmi].

Lang, F. (Yöneten) (1927) Metropolis [Sinema Filmi].

LoBrutto, V. (1992). Interviews with Film Production Designers. Westport, USA: Praeger Publishers.

Monaco, J. (2011). Bir Film Nasıl Okunur. İstanbul: Oğlak Yayıncılık.

Mumford, L. (2007). Tarih Boyunca Kent, Kökenleri, Geçirdiği Dönüşümler ve Geleceği. İstanbul: Ayrıntı Yayınları.

Neumann, D. (2000). Film Architecture: Set Designs Metropolis To Blade Runner. London, UK: Prestel Publishing.

Omay, M. (2009). Ütopya Üzerine Genel Bir İnceleme. Sosyoloji Dergisi 18, 1-14.

Özakın, Ö. (2001). Bugünün Dünyasını Geleceğe Yansıtmak. Arredamento Mimarlık 11, 82-7.

Özen, G. (2006). Bilim Kurgu ve Etki Alanı Üzerinden Geleceğin Yapay Çevrelerinin Değerlendirilmesi. Yüksek Lisans Tezi, İstanbul Teknik Üniversitesi Fen Bilimleri Enstitüsü, İstanbul.

Öztürk, M. (2008). Sinematografik Kentler, Mekânlar, Hatıralar, Arzular. İstanbul: Agora Kitaplığı.

Reyhanoğulları, G. (2012). Türk Edebiyatının İlk Bilim-Kurgu Öyküleri ve Orhan Duru, Turkish Studies, 7, 3, 2183-2197.

Sarı, T. (2010). Türk Sinemasında Sosyal Yaşam Kurgusunun Mekân Kurgusuna Yansıması, Yüksek Lisans Tezi, İstanbul Teknik Üniversitesi Fen Bilimleri Enstitüsü, İstanbul. 
Sayar Güntan, S. (2007). Sinema Aracılığı İle Mimarlığın Sunumu: Wall Street Borsa (1987) Filminin İncelenmesi. Yüksek Lisans Tezi, İstanbul Teknik Üniversitesi Fen Bilimleri Enstitüsü, İstanbul.

Şahin, D., Demir, H., Halifeoğlu, F. M. ve Işık, N. (2019) Diyarbakır’ın Kentsel Gelişiminde Kent Sinemalarının Rolü. Dicle Üniversitesi Fen Bilimleri Enstitüsü Dergisi, 8,1 1-7.

Tykwer T, Wachowski A ve Wachowski L, (Yöneten) (2012) Cloud Atlas [Sinema Filmi].

Türeli, i. (2001). Sinema ve Kentsel Mekânın Dönüşümü. Arredamento Mimarlık 11, 68-72.

Tüzün, S. (2008). Türk Sinemasında Mekân: Tek Mekânda Geçen Filmler. Yüksek Lisans Tezi, Ankara Üniversitesi Sosyal Bilimleri Enstitüsü, Ankara.

Tunçok, M. (2010). Kişisel Mekânın Mimari Temsillerinin 1990 Sonrası Temsillerinin 1990 Sonrası Teni Türk Sinemasında Seçilmiş Filmler Üzerinden Çözümlemesi. Yüksek Lisans Tezi, İstanbul Teknik Üniversitesi Fen Bilimleri Enstitüsü, İstanbul.

Ülker, Ş, Ş. (2011). Mimarlık ve Sinema Ortak Alanında Zamansalık ve Gelecek Mekânları. Yüksek Lisans Tezi, Mimar Sinan Güzel Sanatlar Üniversitesi Fen Bilimleri Enstitüsü, İstanbul.

Yücedağ, ì. (2011). Ütopyalar ve Toplum Sınıflamaları İlişkisi Üzerine, Uluslararası insan Bilimleri Dergisi, 8, 1, 199-212. 


\section{EXTENDED ABSTRACT}

\section{Introduction}

Utopias, which have started to be used in literature, in other words, the idea of the ideal order in the absence of the place, and the Industrial Revolution, which changed the balance of production and consumption, started to be used intensively after the harms of society. In this period, the deepening of class differences and the chaos environment created by them were analyzed and criticized by social utopians, city designers and architects, and concrete solutions were tried to be presented. The designs of the city and city modules and the utopian fiction have evolved towards embodying. The designs that started with this period and shaped with the problems encountered afterwards remained as sketches or individual constructions. Considering the dynamics that the production patterns, energy sources, environmental balance and authority powers constantly change and have changed, it is seen that utopian ideas took place in architectural trends and formations in the 20th century and beyond. Architecture, which is based on the need for shelter, changes with the cultures, beliefs, social and economic conditions, wars, use of energy resources, production/consumption patterns and geographies of societies. Continuously changing and developing architectural approaches have started to represent different formations and ideas by shaping the ideal order with the effect of utopian ideas, the process of creating in the ideal space with the variations of the future. The expressions put forward through representation need to be embraced in the society in order to create an awareness of the future and to spread new ideas and formations. For this reason, while examining the utopian space setup, the ideas of cinema art and architecture, which are the most common and effective communication and perception orientation tool used by societies in different geographies and cultures, were examined.

\section{Method}

A literature review was conducted for the first part of the study. The space fiction of the utopias emerging and developing in the literature are mentioned. How visualized utopias find their place in architecture and prominent designs are given. Spatial change and properties for the utopian and dystopic future constructions developing in different periods in science fiction cinema, another step of visualization, are explained through selected sample films. 


\section{Findings (Results)}

It has been revealed that utopian ideas correspond to dystopic spatial arrangements in the future. Thus, it was observed that there were changes both in the city scale and in the building scale. It is observed that transportation systems and spatial decomposition in the urban scale, and complexes with new functions specific to the number of floors, facade technologies and dystopian constructions in the building scale. In addition, data on the use of technological smart systems in residential arrangements have been revealed and an integrated framework has been created.

\section{Conclusion and Discussion}

The idea of "ideal order", which can be defined as social and individual reaction, has created the concept of utopia by constructing its first products in the literary field. Utopias, which have gained their identity in the literary field, are in connection with the geographical location required for the ideal order that their fiction targets and the architectural elements that shape this place. The architectural utopias, which emerged by offering solutions to the problems of radical change in societies' lifestyles with the change in production and consumption balances, tried to embody the literary and the thought/desired.

With the emergence of utopias as an art, the visualization of the architectural elements used in the depictions of literature in the cinema allowed visualization to be systematic. Architecture, used in literary descriptions, influenced the fiction of cinema films with space creations. Since the architectural elements used in the use of real and fictional spaces in cinema are sometimes used as a means of representation, sometimes as a backdrop, and sometimes as a means of social expression with loaded metaphors and images, the creation of utopian world depictions was created with these uses. Architectural spaces in dystopian fiction, inspired by architectural products and ideas, have taken place in science fiction and have the opportunity to experience in cinema have entered a new process. The examples examined within the scope of the study showed that the architectural utopias of the period are included in science fiction films. Dystopic spaces that are visualized and experienced, have been used as a means of orientation and representation, to perceive and consciousness desired to be created in the society. Utopias turned into dystopias in the 20th century and beyond. Cinema, architecture and literature have created their own utopias with their "language", which includes critical responses to processes such as wars, economic depressions, interstate power races, colonial activities and global warming, such as disruption of natural balance, and the risk of exhaustion of 
energy resources, and trauma and difficult life conditions in societies. Although the ideas of "ideal order" remain utopian, every utopia, from literary to visual concretization, lives its dream of its accessibility, it ends up and derives other utopias in case of irrelevant/universal temporary spatial arrangements. What remains is how much our rights to the future presented to us and what we can do to guide. 